\title{
Nutrient availability and lactogenic hormones regulate mammary protein synthesis through the mammalian target of rapamycin signaling pathway
}

\author{
S. A. Burgos, M. Dai, ${ }^{1}$ and J. P. Cant ${ }^{2}$ \\ Department of Animal and Poultry Science, University of Guelph, Ontario N1G 2W1, Canada
}

\section{ABSTRACT}

The nutritional and endocrine factors affecting protein translation in the bovine mammary gland, and the molecular mechanisms mediating their effects, are not well understood. The objective of this study was to assess the role of the mammalian target of rapamycin (mTOR) signaling pathway in the regulation of mammary protein synthesis by nutrients and hormones. Mammary epithelial acini isolated from lactating dairy cows were treated in medium containing, alone or in combination, a mixture of AA or glucose and acetate (GA) as energy substrates, or a combination of the lactogenic hormones hydrocortisone, insulin, and prolactin (HIP). Changes in the rate of mammary protein synthesis and the phosphorylation state of components of the mTOR signaling pathway were measured. Mammary protein synthesis was $50 \%$ higher with increased availability of AA in medium. The presence of GA or treatment of mammary acini with HIP alone did not affect mammary protein synthesis. The stimulation of mammary protein synthesis by AA was enhanced by HIP treatment, but not by the presence of GA in medium. Treatment of mammary acini with HIP induced the phosphorylation of protein kinase B. This effect was augmented in the presence of either AA or GA in medium. The stimulation of mammary protein synthesis by AA and its enhancement by HIP were associated with increased phosphorylation of the mTOR substrates, p70 ribosomal protein S6 kinase-1, and eukaryotic initiation factor $4 \mathrm{E}$ (eIF4E)-binding protein-1 (4E-BP1), and dissociation of 4E-BP1 from eIF4E. The results suggest that nutrients and hormones may modulate mammary protein synthesis through the mTOR signaling pathway.

Key words: protein synthesis, mammalian target of rapamycin, mammary gland

Received June 2, 2009.

Accepted September 18, 2009.

${ }^{1}$ Current address: Hormones and Cancer Research Unit, Department of Medicine, Royal Victoria Hospital, McGill University, 687 Pine Avenue West, Montreal, Quebec H3A 1A1, Canada.

${ }^{2}$ Corresponding author: jcant@uoguelph.ca

\section{INTRODUCTION}

Milk protein is an important component of milk and a source of nutrition for human consumption. The yield of milk protein is tightly regulated and varies widely among animals (Jenness, 1979). The variability in milk protein content may be associated with differences in nutritional and endocrine factors that influence protein metabolism in the mammary gland (DePeters and Cant, 1992; Mackle et al., 2000). In other tissues, such as skeletal muscle and liver, nutrients and hormones modulate protein metabolism through changes in the protein translational apparatus (Kimball et al., 2000; O'Connor et al., 2003). Recent studies have indicated that regulation of protein translation may be important in determining milk protein production by dairy cows (Toerien and Cant, 2007; Hayashi et al., 2009). However, the factors affecting protein translation in the bovine mammary gland and the molecular mechanisms mediating their effects remain largely unknown.

Protein synthesis consumes AA and ATP, and an adequate supply of both is essential to meet the demands of lactation. Indeed, studies utilizing stable isotope labeling have shown that the capacity of the mammary gland to extract AA is important for mammary and milk protein production (Bequette et al., 1998). The lactating mammary gland also requires an adequate energy supply. Hanigan et al. (2009) estimated that almost half of the ATP generated by the lactating mammary gland is used for synthesis of proteins. Studies in animal and cell culture models have revealed that AA and cellular energy availability play a role in regulating protein synthesis not only as substrates but also through direct signaling to the protein synthetic machinery (Proud, 2007).

Endocrine signals also regulate milk protein synthesis. Early studies demonstrated that the lactogenic hormones hydrocortisone, insulin, and prolactin (HIP) are required for maximal accumulation of milk protein gene transcripts in organ culture (Houdebine et al., 1985). Studies in cultured mouse mammary epithelial cells have established that, in addition to transcriptional activation, HIP modulate milk protein synthesis through 
general stimulation of the translational machinery and differential enhancement of milk protein mRNA translation (Rhoads and Grudzien-Nogalska, 2007). Lactogenic hormones stimulate general translation through phosphorylation-induced changes in the activity of components of the protein synthesis machinery that are mediated, at least in part, by the phosphatidylinositol 3-kinase $(\mathbf{P I 3 K})$ /protein kinase B (PKB; also known as Akt) pathway (Barash, 1999). The enhancement of milk protein mRNA translation appeared to occur as a result of stabilization of the transcript via lengthening of the poly(A) tail on milk protein mRNA (Choi et al., 2004). Whether HIP induce changes in the phosphorylation state of proteins involved in the regulation of protein translation to modulate protein synthesis in bovine mammary cells has not been established.

The effects of nutrients and hormones on protein translation are mediated by mammalian target of rapamycin (mTOR) signaling (Yang et al., 2008). The mTOR signaling cascade integrates amino acid availability, cellular energy status, and endocrine signals to regulate protein synthesis through changes in the phosphorylation status of eukaryotic initiation factor 4E (eIF4E)-binding protein-1 (4E-BP1), a translational repressor, and p70 ribosomal protein S6 kinase-1 (S6K1). Phosphorylation of 4E-BP1 results in its dissociation from eIF4E, thereby facilitating eIF4E binding to eIF4G to form complexes that are competent for cap-dependent translation (Gingras et al., 1999). Phosphorylation of S6K1 leads to activation of several components of the protein translation apparatus (Ma and Blenis, 2009).

The objective of this study was to establish the role of mTOR signaling in mediating the effects of AA and glucose and acetate (GA) availability as well as HIP on protein synthesis in the bovine mammary gland. To investigate the direct effects of nutrients and hormones on bovine mammary epithelial cells, in the absence of potential confounding systemic effects of treatments, the experiments were conducted in mammary acini freshly isolated from lactating dairy cows.

\section{MATERIALS AND METHODS}

\section{Preparation and Incubation of Mammary Acini}

Multiparous lactating Holstein cows from the Elora Dairy Research Station (University of Guelph) were slaughtered at the Meat Science Laboratory (University of Guelph). Mammary acini were prepared essentially as described by Baumrucker et al. (1988) with minor modifications. Briefly, immediately after exsanguination, several pieces of tissue were aseptically removed from the mammary gland. Tissue samples were trimmed of visible connective and adipose tissue, weighed (50 g), finely minced (approximately $1 \mathrm{~mm}^{2}$ ), and washed 6 times with Krebs-Ringer HEPES buffer (KRHB; 25 $\mathrm{m} M$ HEPES, $\mathrm{pH}$ 7.4, $118 \mathrm{~m} M \mathrm{NaCl}, 4.7 \mathrm{~m} M \mathrm{KCl}, 1.2$ $\mathrm{m} M \mathrm{MgSO}_{4}, 2.5 \mathrm{~m} M \mathrm{CaCl}_{2}, 1.2 \mathrm{~m} M \mathrm{KH}_{2} \mathrm{PO}_{4}$ ) by decantation. Minced tissue was suspended in $250 \mathrm{~mL}$ of KRHB containing 350 units/mL of collagenase type 3 (Worthington Biochemical, Lakewood, NJ) and 0.04\% deoxyribonuclease I (Worthington Biochemical) and incubated at $37^{\circ} \mathrm{C}$ with constant shaking at 120 cycles/ $\min$ for $3 \mathrm{~h}$. Digested tissue was filtered through a 205$\mu \mathrm{m}$ polypropylene mesh, and the filtered digest was centrifuged at $500 \times g$ for $5 \mathrm{~min}$. The supernatant was discarded and the acini pellet was suspended in fresh KRHB. Mammary acini were washed by centrifugation, decantation, and resuspension as above a total of 5 times. Mammary acini were resuspended in KRHB and DNA concentration was measured using a fluorometric assay (Sigma-Aldrich, Oakville, Ontario, Canada) according to Labarca and Paigen (1980) with calf thymus DNA as standard. The concentration of DNA in the acini suspension was standardized to $10 \mu \mathrm{g}$ of DNA/ $\mathrm{mL}$ of KRHB.

Isolated mammary acini were preincubated in KRHB at $37^{\circ} \mathrm{C}$ for $1 \mathrm{~h}$. Aliquots of $1 \mathrm{~mL}$ of cell suspension in microcentrifuge tubes were incubated at $37^{\circ} \mathrm{C}$ with constant gentle rotation for $1 \mathrm{~h}$ in either prewarmed KRHB (control) or KRHB containing a mixture of AA, GA, or HIP, alone or in combination (AA-GA, AAHIP, GA-HIP, AA-GA-HIP). The final concentration of each L-amino acid in the AA mixture was 4 times the arterial concentration of AA reported by Mackle et al. (2000) for well-fed lactating cows $(\mu M)$ : Ala, 715; Arg, 330; Asp, 45; Asn, 204; Cys, 48; Glu, 254; Gln, 685, Gly, 785; His, 195; Ile, 499; Leu, 671; Lys, 333; Met, 79; Phe, 190; Pro, 285; Ser, 287; Thr, 427; Trp, 114; Tyr, 209; and Val, 1,063. The final concentrations of glucose and acetate (as sodium salt) were $12 \mathrm{mM}$ each. When present, the hydrocortisone, insulin, and prolactin were added at a final concentration of $1 \mu \mathrm{g} / \mathrm{mL}$ each. Media components and hormones were of cell culture grade from Sigma-Aldrich. All treatment media were isosmotic (290 to $310 \mathrm{mOsm} / \mathrm{kg}$ of $\mathrm{H}_{2} \mathrm{O}$ ) and had a final $\mathrm{pH}$ of $7.4 \pm 0.05$. In parallel experiments, mammary acini were resuspended in treatment media containing L- $\left[2,3,4,5,6-{ }^{3} \mathrm{H}\right]$ Phe $(10 \mu \mathrm{Ci} / \mathrm{mL}$; GE Healthcare, Piscataway, NJ) and Phe at $190 \mu M$. Acini suspensions were incubated at $37^{\circ} \mathrm{C}$ with constant gentle rotation for $1 \mathrm{~h}$. Incubation was terminated by centrifugation at $800 \times g$ for $1 \mathrm{~min}$. The spent medium was quickly discarded and the acini pellet immediately frozen in liquid nitrogen before storage at $-80^{\circ} \mathrm{C}$. 


\section{Preparation of Cell Lysate}

Mammary acinar proteins were extracted in ice-cold lysis buffer (50 m $M$ Tris- $\mathrm{HCl}, \mathrm{pH} 7.4,150 \mathrm{~m} M \mathrm{NaCl}, 1 \%$ Triton X-100, $1 \mathrm{~m} M$ EDTA, $50 \mathrm{~m} M \beta$-glycerolphosphate, $50 \mathrm{~m} M \mathrm{NaF}, 10 \mathrm{~m} M \mathrm{Na}_{4} \mathrm{P}_{2} \mathrm{O}_{7}, 0.5 \mathrm{~m} M \mathrm{Na}_{3} \mathrm{VO}_{4}, 1 \mathrm{~m} M$ phenylmethylsulfonyl, $10 \mu M$ aprotinin, $10 \mu M$ leupeptin, and $2 \mu M$ pepstatin) at $4^{\circ} \mathrm{C}$ for 15 min with gentle rotation. The lysate was cleared by centrifugation at $15,000 \times g$ at $4^{\circ} \mathrm{C}$ for $15 \mathrm{~min}$. An aliquot of cell lysate was used to measure protein concentration by the bicinchoninic acid method (Pierce Biotechnology, Rockford, IL) using BSA as standard.

\section{Measurement of Mammary Protein Synthesis}

To $0.5 \mathrm{~mL}$ of cell lysate, an equal volume of ice-cold $20 \%$ TCA was added. The samples were kept on ice for $30 \mathrm{~min}$ and then centrifuged at $15,000 \times g$ for $5 \mathrm{~min}$. The pellets were washed 3 times by resuspension and centrifugation with 5\% TCA. The protein pellet was dissolved in $80 \%$ formic acid. The solubilized protein was transferred to scintillation vials and radioactivity was determined by liquid scintillation counting using Ecolite scintillation fluid (ICN, Costa Mesa, CA) in a Beckman liquid scintillation counter (LS 6000, Beckman Instruments, Fullerton, CA).

\section{Immunoblotting and Immunoprecipitation}

Mammary acinar proteins were extracted and lysate cleared as described previously. An aliquot of cleared lysate was mixed with an equal volume of $2 \times$ SDS sample buffer and then heated at $95^{\circ} \mathrm{C}$ for $5 \mathrm{~min}$. Equal amounts of protein $(50 \mu \mathrm{g})$ were loaded onto polyacrylamide gels (8\% for PKB and S6K1; $15 \%$ for 4E-BP1), subjected to SDS-PAGE (150 V for 90 to $120 \mathrm{~min}$ ), and transferred to a polyvinylidene fluoride membrane (Bio-Rad Laboratories, Hercules, CA). The membranes were blocked for $1 \mathrm{~h}$ at room temperature in $5 \%$ (wt/ vol) nonfat dried milk in Tris-buffered saline containing $0.1 \%$ Tween 20 (TBS-T) and then incubated with phospho-specific primary antibodies diluted 1:1,000 in TBS-T containing 5\% nonfat dried milk overnight at $4^{\circ} \mathrm{C}$. Membranes were washed 3 times for 5 min each in TBS-T and subsequently incubated with secondary antibody (GE Healthcare) in TBS-T containing $5 \%$ nonfat dried milk for $1 \mathrm{~h}$ at room temperature. Immunoblots were developed with an enhanced chemiluminescence detection kit (GE Healthcare) and analyzed by densitometry using NIH Image/J Software (available at rsb. info.nih.gov/ij). After detection of the phospho-specific signal, the antibodies were stripped off the membrane by incubation in stripping buffer $(62.5 \mathrm{mM}$ Tris- $\mathrm{HCl}$,
$100 \mathrm{~m} M \beta$-mercaptoethanol, and $2 \%$ SDS) at $50^{\circ} \mathrm{C}$ for $30 \mathrm{~min}$. After stripping, the membranes were incubated with enhanced chemiluminescence detection reagents and exposed to film to ensure effective removal of signals from phospho-specific antibodies according to the manufacturer's instructions. The membranes were washed, blocked, and reprobed with primary antibodies that recognized the protein irrespective of their phosphorylation state at a dilution of 1:500 for PKB and S6K1 or 1:5,000 for 4E-BP1. The densities of phosphorylated signals were normalized to total protein levels. Phosphorylation of 4E-BP1 retards the electrophoretic mobility of the protein on SDS-PAGE resulting in multiple electrophoretic forms. All the bands within one lane in phosphorylated and total 4E-BP1 blots were selected for densitometry analysis. Primary antibodies against phospho-PKB $\left(\mathrm{Ser}^{473}\right)$, phospho-S6K $\left(\mathrm{Thr}^{389}\right)$, total PKB, and total S6K were from Santa Cruz Biotechnology (Santa Cruz, CA), whereas phospo-4E-BP1 $\left(\mathrm{Thr}^{70}\right)$ and total 4E-BP1 were from Cell Signaling Technology (Beverly, MA).

To examine the association between $4 \mathrm{E}-\mathrm{BP} 1$ and eIF4E, the amount of $4 \mathrm{E}-\mathrm{BP} 1$ in the eIF4E immunoprecipitate was examined by immunoblotting for eIF4E and 4E-BP1 after immunoprecipitation of eIF4E. Mammary acini cell lysates (0.5 $\mathrm{mg}$ of protein) were incubated with $20 \mu \mathrm{L}$ of agarose-conjugated anti-mouse eIF4E antibody (Santa Cruz Biotechnology) in spin columns (0.7-mL polypropylene column fitted with a 7- to $20-\mu \mathrm{m}$ polyethylene frit) with breakaway tip (Sigma-Aldrich) at $4^{\circ} \mathrm{C}$ with rotation for $2 \mathrm{~h}$. Beads were collected by centrifugation and washed 3 times in lysis buffer. To elute immunoprecipitated complexes, the beads were resuspended in $2 \times$ SDS sample buffer and heated at $95^{\circ} \mathrm{C}$ for $5 \mathrm{~min}$. The eluate was loaded onto $15 \%$ polyacrylamide gels, subjected to SDS-PAGE, and subsequently transferred onto membranes, as described above. Membranes were blotted using antibodies to either eIF4E (Santa Cruz Biotechnology) or 4E-BP1, at $1: 500$ or 1:1,000 dilution, respectively. Blots were developed and analyzed as described previously, and the abundance of $4 \mathrm{E}-\mathrm{BP} 1$ was normalized to the amount of eIF4E in the immunoprecipitate.

\section{Statistical Analysis}

Data are presented as mean \pm SEM. Results are from 6 replicates per treatment group from mammary acini collected from 2 cows on separate occasions (3 replicates/treatment group per cow). Data were analyzed by ANOVA using the General Linear Model procedure of SAS (SAS Institute, 2000) with cow and treatment group as the dependent variables. The effect of cow was not significant for any of the variables measured. When 


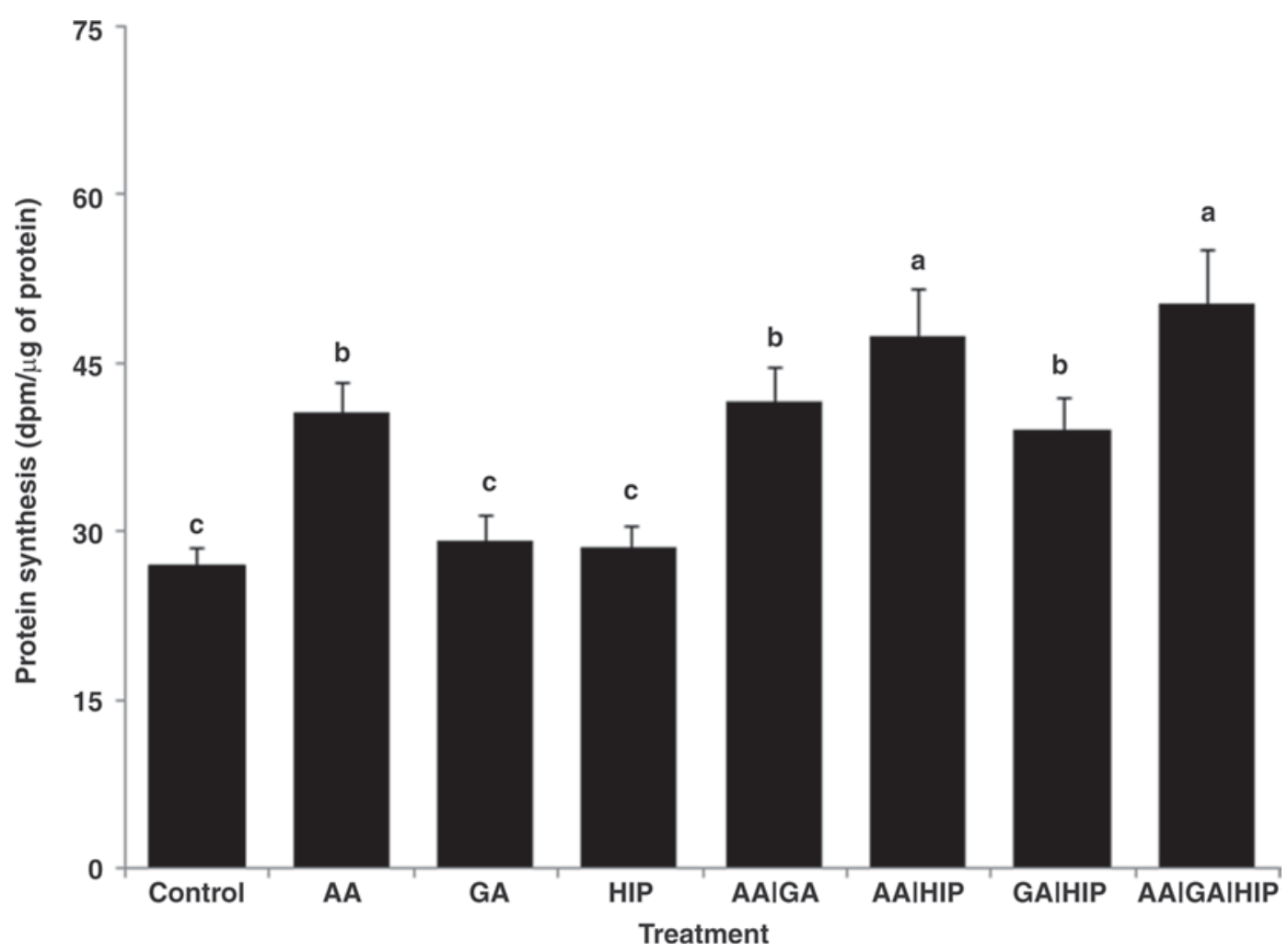

Figure 1. Effect of AA; glucose and acetate (GA); and hydrocortisone, insulin, and prolactin (HIP) alone or in combination, on protein synthesis in bovine mammary acini. Values are means $\pm \mathrm{SEM}, \mathrm{n}=6 .{ }^{\mathrm{a}-\mathrm{c}}$ Means not sharing a common letter differ, $P<0.05$.

an overall effect was detected, differences between treatment means were assessed with the PDIFF option. Differences were considered significant at $P<0.05$.

\section{RESULTS}

The effects of nutrient availability and HIP on mammary protein synthesis are presented in Figure 1. Incubation of mammary acini in a medium containing $4 \times$ the arterial concentration of AA in fed lactating dairy cows stimulated protein synthesis by $50 \%$ within $1 \mathrm{~h}$ of incubation. In contrast, mammary protein synthesis was unaffected by increased supply of glucose and acetate or HIP treatment ( $P=0.91$ and 0.97 , respectively). The ability of AA to stimulate mammary protein synthesis was independent of GA availability, as the presence of both AA and GA in medium did not result in a greater rate of protein synthesis compared with that achieved with AA alone $(P=0.94)$. Treatment of mammary acini with HIP in medium containing glucose and acetate resulted in a $35 \%$ increase in protein synthesis relative to control. In addition, HIP slightly enhanced the stimulation of protein synthesis by AA relative to the effect of AA alone. Mammary protein synthesis, at the concentrations used in this study, was greatest in the presence of AA and HIP, as further addition of GA was without effect $(P=0.83)$.

The PI3K/PKB signaling pathway is involved in insulin and prolactin stimulation of protein synthesis in mouse mammary cells (Barash, 1999). To assess whether this pathway is involved in the upregulation of mammary protein synthesis by nutrients and hormones, we measured the phosphorylation state of PKB at $\operatorname{Ser}^{473}$. The availability of AA alone had no effect $(P=0.96)$ on PKB phosphorylation in mammary epithelial cells compared with control (Figure 2). The presence of GA alone in medium did not significantly increase PKB phosphorylation over control values $(P$ $=0.11$ ). The combination of AA and GA in medium did not stimulate PKB phosphorylation above control values $(P=0.07)$ and neither did GA alone $(P=0.82)$. Treatment of mammary acini with HIP led to a 10-fold increase in phosphorylation of PKB in the absence of nutrients in the medium. There was a 2 -fold increase in PKB phosphorylation when either AA or GA supply in medium was increased $(P<0.001)$.

To assess whether the effects of nutrients and HIP on mammary protein synthesis are mediated through the mTOR signaling pathway, the phosphorylation of S6K1 at $\mathrm{Thr}^{389}$ and $4 \mathrm{E}-\mathrm{BP} 1$ at $\mathrm{Thr}^{70}$ was measured as 

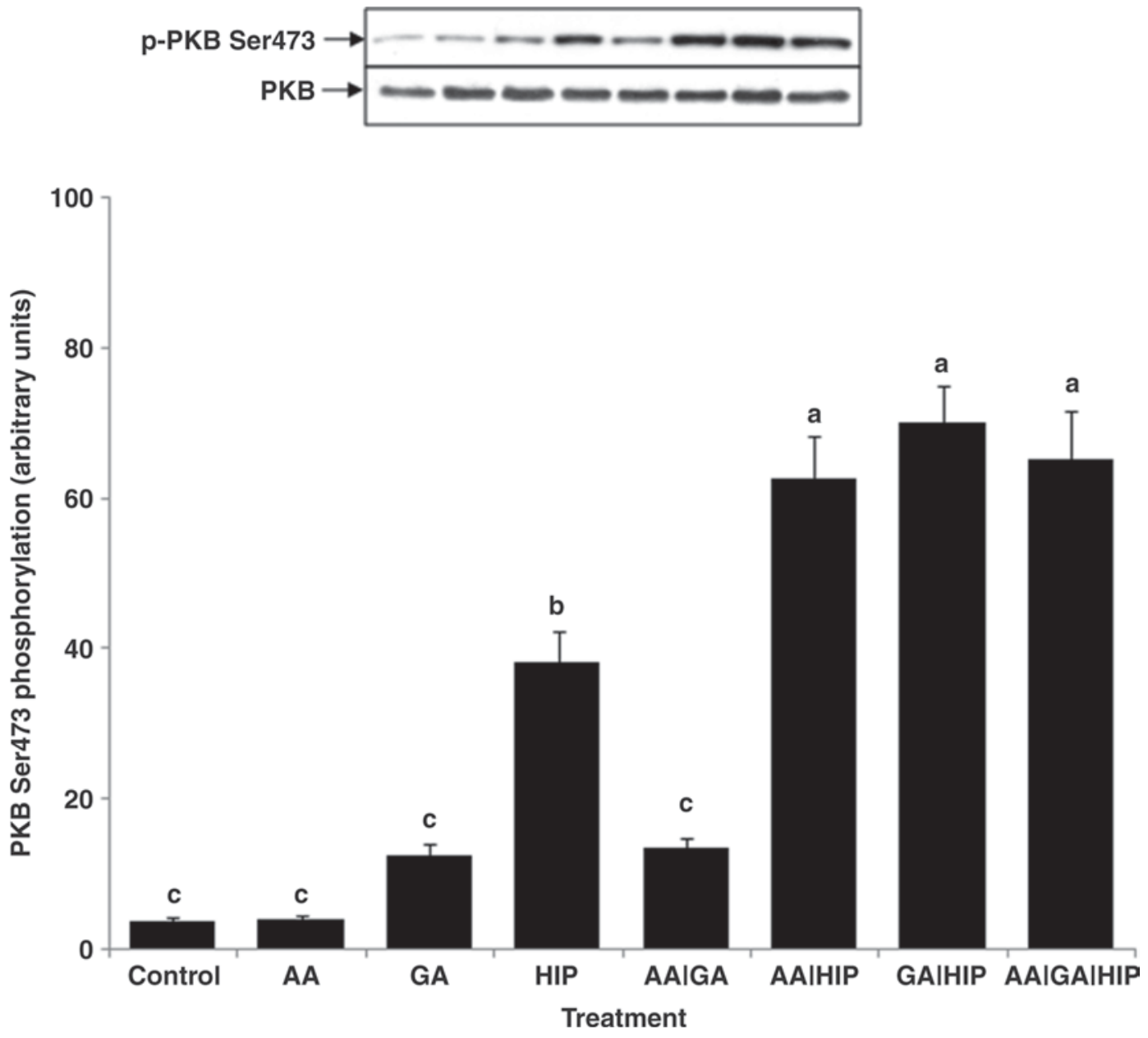

Figure 2. Effect of AA; glucose and acetate (GA); and hydrocortisone, insulin, and prolactin (HIP) alone or in combination, on protein kinase $\mathrm{B}(\mathrm{PKB})$ phosphorylation at $\mathrm{Ser}^{473}$ in bovine mammary acini. Values are means $\pm \mathrm{SEM}, \mathrm{n}=6 .{ }^{\mathrm{a}-\mathrm{c}}$ Means not sharing a common letter differ, $P<0.05$.

a readout of the activation state of mTOR signaling (Hay and Sonenberg, 2004). Phosphorylation of S6K1 (Figure 3) and 4E-BP1 (Figure 4) increased about 9-fold in response to higher AA availability. Increasing the concentration of GA in basal medium or treatment with HIP alone had no effect on phosphorylation of S6K or 4 E-BP1 $(P>0.24)$. However, when both conditions were combined, phosphorylation of S6K and 4E-BP1 were 3 - and 6-fold higher, respectively, than in basal medium. The induction of S6K1 and 4E-BP1 phosphorylation by AA supply was enhanced by HIP treatment, with no further increase by supplementation of basal medium with GA.

An important step in the regulation of translation initiation is assembly of the eIF4F complex, which is limited by the availability of eIF4E (Gingras et al., 1999). The availability of eIF4E is regulated in part by its association to $4 \mathrm{E}-\mathrm{BP} 1$. Binding of $4 \mathrm{E}-\mathrm{BP} 1$ to eIF4E is dependent on the phosphorylation status of $4 \mathrm{E}-\mathrm{BP} 1$. Increased phosphorylation of $4 \mathrm{E}-\mathrm{BP} 1$ results in decreased affinity for eIF4E. Therefore, we evaluated the association of eIF4E with 4E-BP1. As expected, the phosphorylation of $4 \mathrm{E}-\mathrm{BP} 1$ at $\mathrm{Thr}^{70}$ was inversely correlated with the amount of $4 \mathrm{E}-\mathrm{BP} 1$ bound to eIF4E (Figure 5). Consistent with the effect of AA on protein synthesis and 4E-BP1 phosphorylation, we found that the amount of 4E-BP1 bound to eIF4E decreased in the presence of AA either alone or in combination with GA or HIP $(P<0.001)$.

\section{DISCUSSION}

The mTOR signaling pathway is responsible for the stimulation of protein synthesis in liver and muscle of growing animals in response to changes in nutritional and endocrine status (Kimball et al., 2000; O'Connor et al., 2003). In cultures of mammary acini isolated from bovine mammary glands, we found that effects of nutrient and hormone additions, separately and in combination, on the mTOR targets S6K1 and 4E-BP1 were 

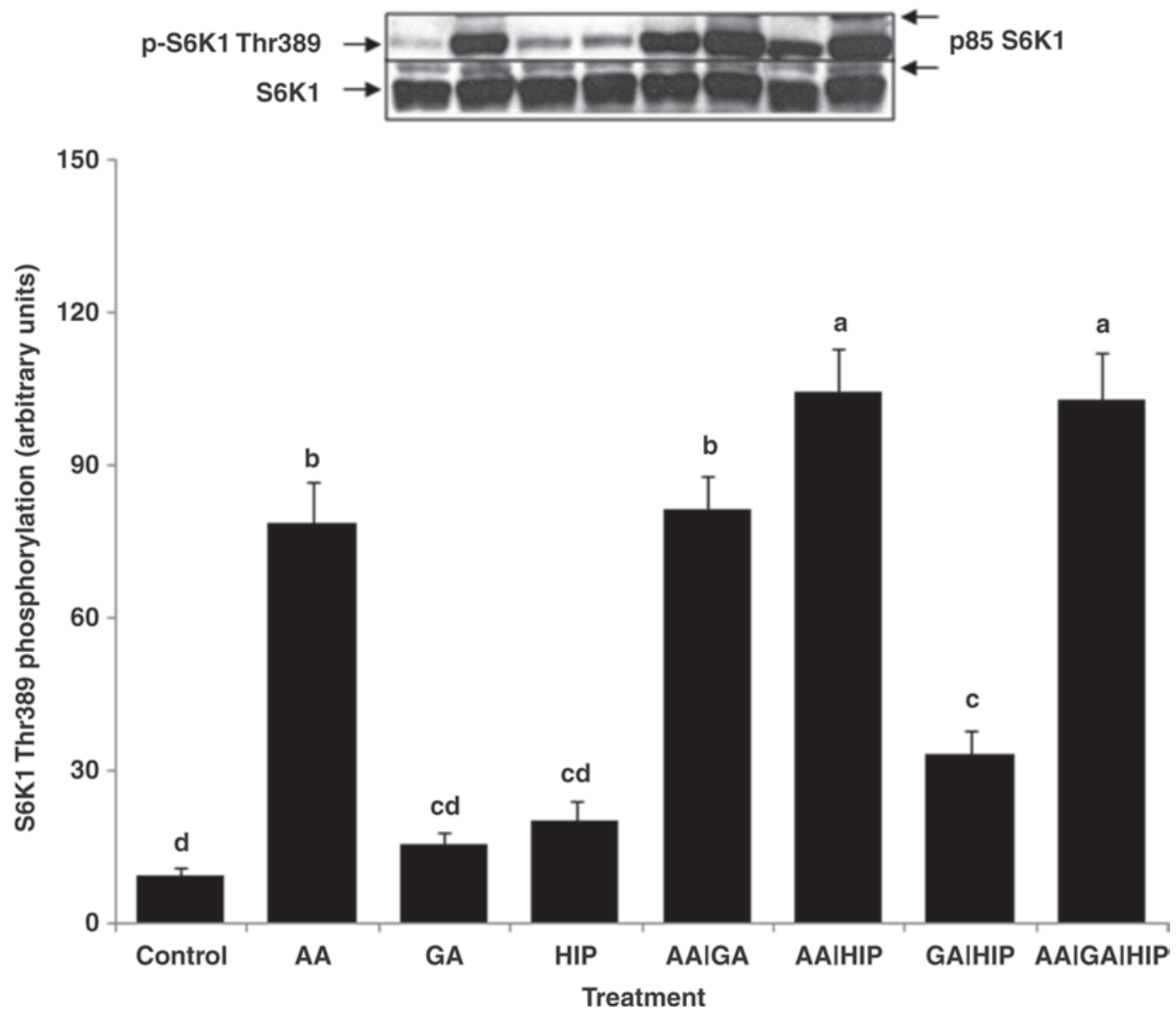

Figure 3. Effect of AA; glucose and acetate (GA); and hydrocortisone, insulin, and prolactin (HIP) alone or in combination, on p70 ribosomal protein S6 kinase-1 (S6K1) phosphorylation at $\mathrm{Thr}^{389}$ in bovine mammary acini. Values are means \pm SEM, $\mathrm{n}=6{ }^{a-d}$ Means not sharing a common letter differ, $P<0.05$.

reflected in rates of protein synthesis. Early studies in dispersed bovine mammary epithelial cells showed that the synthesis of the milk-specific proteins $\beta$-casein and $\beta$-lactoglobulin increased as a function of AA concentration in the culture medium (Schingoethe et al., 1967; Park and Chandler, 1976). The acute stimulation of protein synthesis in isolated bovine mammary acini by AA was associated with increased phosphorylation of S6K1 and $4 \mathrm{E}-\mathrm{BP} 1$ and dissociation of 4E-BP1 from eIF4E, suggesting that effects of AA on protein translation may be mediated by the mTOR signaling pathway. Consistent with results from the present study, re-addition of AA stimulated total mammary and $\beta$-lactoglobulin synthesis in 72-h AA-deprived cultured murine or bovine mammary epithelial cells in a rapamycin-sensitive manner (Moshel et al., 2006). However, summaries of published research show poor milk protein responses to increased AA supply to the mammary gland in normally fed cows (Hanigan et al., 1998). Therefore, it is likely that additional mechanisms play a dominant role in determining the milk protein response to AA supply in lactating dairy cows. Previous nutritional plane may be such a determinant, because the greatest responses to increasing AA supply by casein infusion have been observed in cows fed diets deficient in AA (Whitelaw et al., 1986).

Restoring GA to nutrient-deprived mammary acini did not affect protein synthesis or activation state of the mTOR signaling cascade, as assessed by S6K1 and 4E-BP1 phosphorylation. In lactating dairy cows, intravenous infusion of glucose for $7 \mathrm{~h}$ into cows previously fasted for $22 \mathrm{~h}$ resulted in an increase in milk protein yield without an effect on S6K1 phosphorylation (Toerien et al., 2004), whereas close arterial infusion of acetate for $10 \mathrm{~h}$ in fed lactating dairy cows did not affect milk protein yield (Purdie et al., 2008). Whether the supply of energy-yielding substrates to the mammary gland regulates milk protein yield and by which mechanisms warrant further investigation.

In the present study, a mixture of HIP acutely promoted mammary protein synthesis, but only in the presence of AA or GA. The effects of HIP on protein 

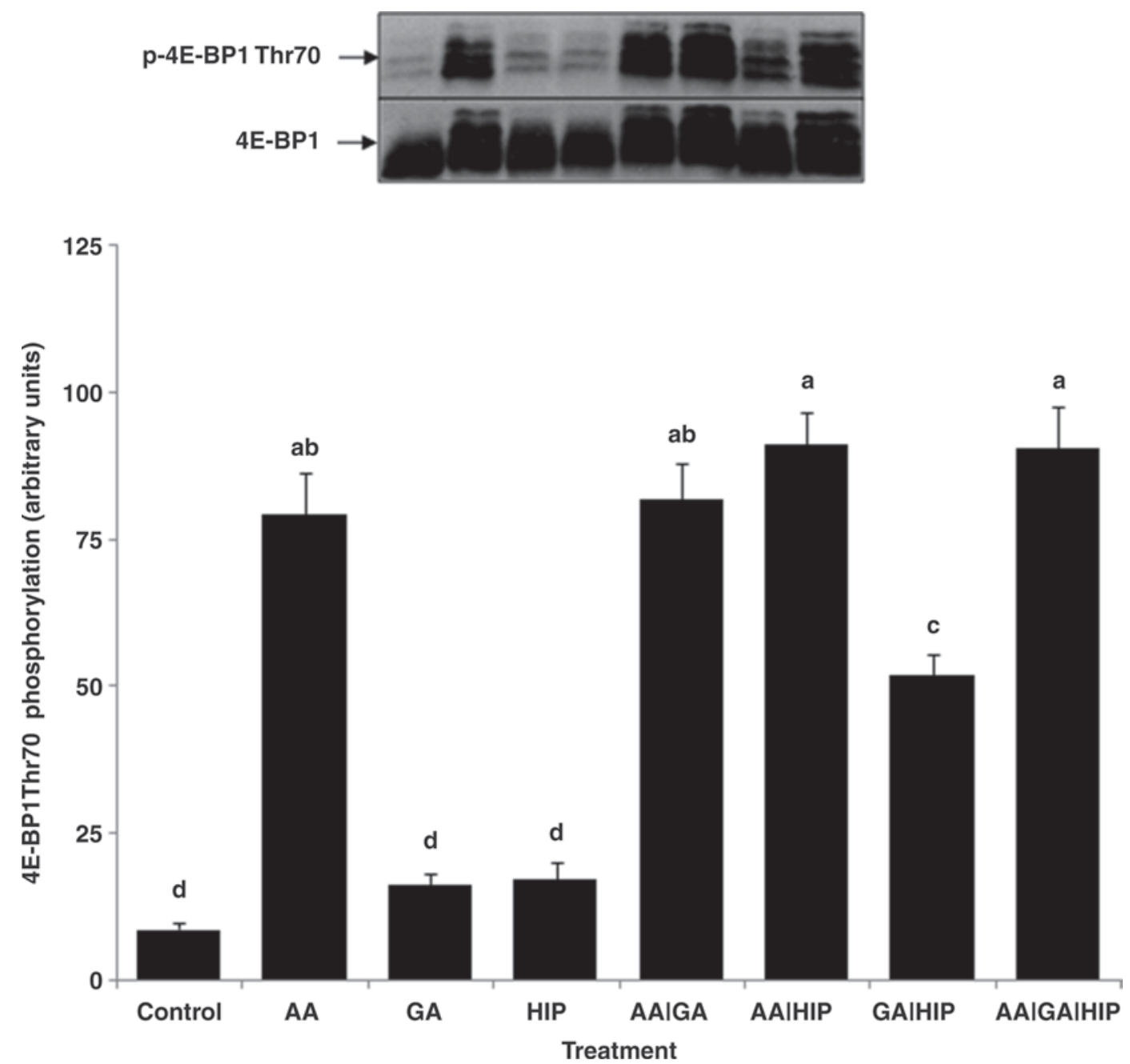

Figure 4. Effect of AA; glucose and acetate (GA); and hydrocortisone, insulin, and prolactin (HIP) alone or in combination, on eukaryotic initiation factor $4 \mathrm{E}$ (eIF4E)-binding protein-1 (4E-BP1) phosphorylation at $\mathrm{Thr}^{70}$ in bovine mammary acini. Values are means $\pm \mathrm{SEM}, \mathrm{n}=6$. ${ }^{a-d}$ Means not sharing a common letter differ, $P<0.05$.

synthesis were associated with increased phosphorylation of S6K1 and 4E-BP1 as well as dissociation of 4E-BP1 from eIF4E. The effects of lactogenic hormones on protein synthesis were mediated at least in part by induction of the insulin signaling pathway, as HIP independently stimulated PKB phosphorylation. A combination of HIP was used in the current study, because it has been shown that all are required for transcriptional activation of milk protein genes (Houdebine et al., 1985). However, specific combinations of hormones may have different effects. For example, insulin and prolactin have previously been found to synergistically stimulate total protein synthesis in mouse mammary epithelial cells in culture through phosphorylation of 4E-BP1 (Barash, 1999), whereas glucocorticoids have been shown to downregulate mTOR signaling and inhibit protein synthesis in skeletal muscle cells (Shah et al., 2000).
The mTOR signaling pathway integrates multiple inputs to regulate protein translation (Ma and Blenis, 2009). We found that the availability of nutrients (either AA or GA) was required for HIP to increase the phosphorylation of S6K1 and 4E-BP1 and protein synthesis in mammary epithelial cells. Previous studies have shown that availability of $\mathrm{AA}$ is required for activation of mTOR signaling (Hara et al., 1998). The PI3K/PKB signal transduction pathway regulates mTOR signaling by modulating the activation state of Rheb, a small $\mathrm{G}$ protein that binds to and activates mTOR kinase activity (Long et al., 2005; Sancak et al., 2007). The molecular mechanisms of AA induction of mTOR signaling are just beginning to be elucidated. Recent studies have revealed that AA do not directly activate mTOR, but rather promote the intracellular localization of mTOR to a compartment that also contains its activator, Rheb (Sancak and Sabatini, 2009). Further studies will be re- 

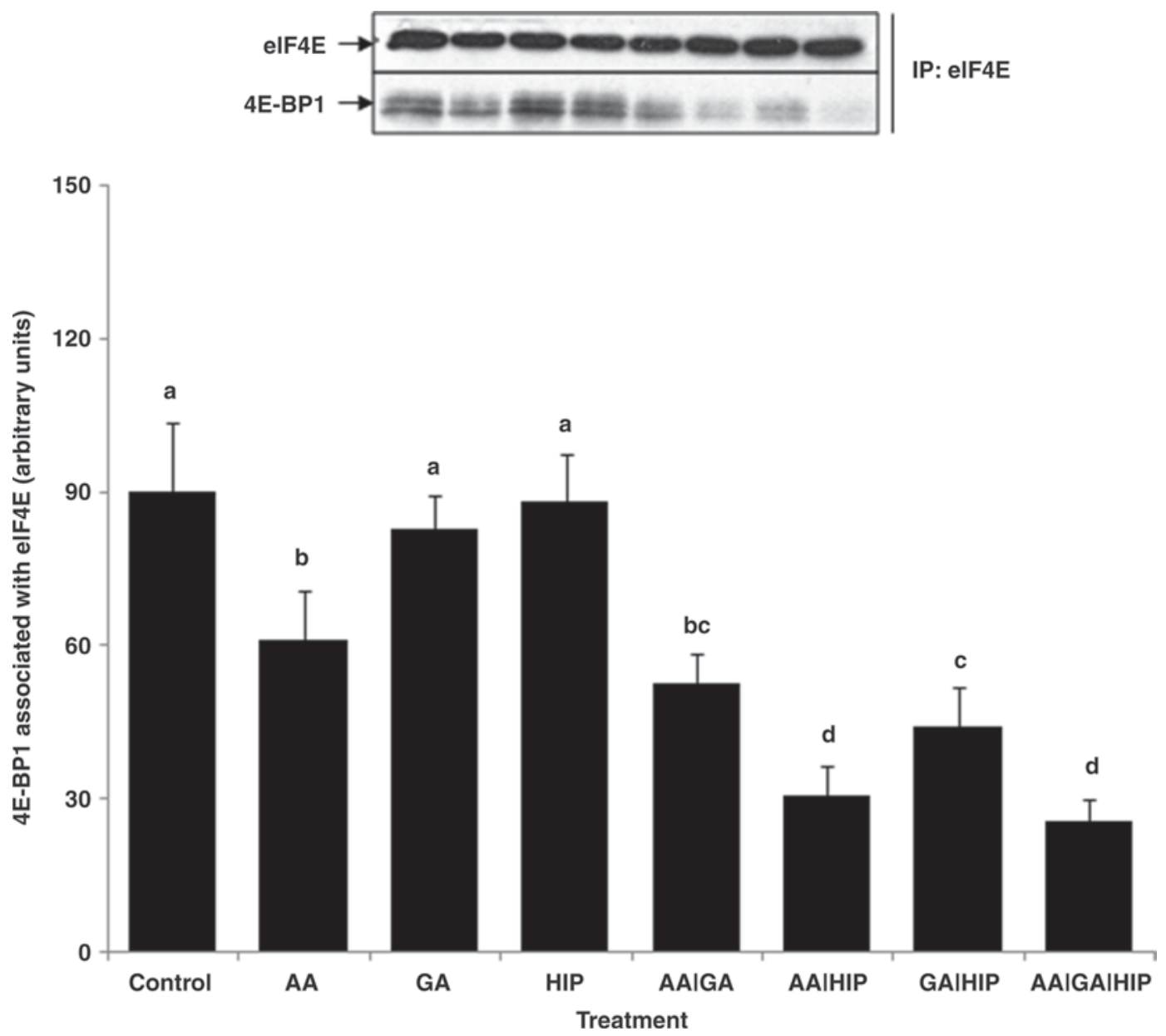

Figure 5. Effect of AA; glucose and acetate (GA); and hydrocortisone, insulin, and prolactin (HIP) alone or in combination, on association of eukaryotic initiation factor $4 \mathrm{E}$ (eIF4E)-binding protein-1 (4E-BP1) with eIF4E. Values are means \pm SEM, $\mathrm{n}=6 .{ }^{\mathrm{a}-\mathrm{d}} \mathrm{Means}$ not sharing a common letter differ, $P<0.05$. IP $=$ immunoprecipitate.

quired to elucidate the molecular mechanism by which lactogenic hormones and AA induce phosphorylation of S6K1 and 4E-BP1 in bovine mammary epithelial cells.

We also observed that the HIP-induced PKB phosphorylation was enhanced in the presence of $\mathrm{AA}$ or GA in medium. This was unexpected, as previous studies have shown that nutrients do not alter the ability of insulin to activate insulin signaling in liver or muscle of neonatal pigs (Suryawan et al., 2004). Nonetheless, studies in isolated rat pancreatic acini suspension showed that addition of any branched-chain AA stimulated PKB phosphorylation at $\operatorname{Ser}^{473}$ (Sans et al., 2006). Therefore, the ability of nutrients to modulate activation of PKB may be tissue- or species-specific.

The findings from this study show that nutrient availability and hormones may modulate the activation state of the mTOR signaling pathway to regulate the rate of protein translation in bovine mammary cells. Further research will be required to determine whether the mTOR signaling pathway is directly involved in the regulation of mammary protein synthesis and to establish the significance of mTOR-mediated regulation of protein translation on milk protein yield by nutrients and endocrine signals in lactating dairy cows. In this regard, recent work by Hayashi et al. (2009) has shown that injection of slow-release growth hormone into lactating dairy cows increased milk protein yield through changes in mRNA translation initiation and elongation that may have been mediated by the mTOR signaling pathway, suggesting that integration of nutrient and endocrine signals by the mTOR signaling cascade may be a control point for milk protein synthesis.

\section{ACKNOWLEDGMENTS}

The authors acknowledge the assistance of staff at the Elora Dairy Research Centre (University of Guelph, Ontario, Canada), and the Meat Laboratory (Univer- 
sity of Guelph) is gratefully acknowledged. Financial support for this work was provided by NSERC Canada and Dairy Farmers of Canada.

\section{REFERENCES}

Barash, I. 1999. Prolactin and insulin synergize to regulate the translation modulator PHAS-I via mitogen-activated protein kinase-independent but wortmannin- and rapamycin-sensitive pathway. Mol. Cell. Endocrinol. 155:37-49.

Baumrucker, C. R., K. P. Deemer, R. Walsh, T. L. Riss, and R. M. Akers. 1988. Primary culture of bovine mammary acini on a collagen matrix. Tissue Cell 20:541-554.

Bequette, B. J., F. R. Backwell, and L. A. Crompton. 1998. Current concepts of amino acid and protein metabolism in the mammary gland of the lactating ruminant. J. Dairy Sci. 81:2540-2559.

Choi, K. M., I. Barash, and R. E. Rhoads. 2004. Insulin and prolactin synergistically stimulate beta-casein messenger ribonucleic acid translation by cytoplasmic polyadenylation. Mol. Endocrinol. 18:1670-1686.

DePeters, E. J., and J. P. Cant. 1992. Nutritional factors influencing the nitrogen composition of bovine milk: A review. J. Dairy Sci. 75:2043-2070.

Gingras, A. C., B. Raught, and N. Sonenberg. 1999. eIF4 initiation factors: Effectors of mRNA recruitment to ribosomes and regulators of translation. Annu. Rev. Biochem. 68:913-963.

Hanigan, M. D., J. P. Cant, D. C. Weakley, and J. L. Beckett. 1998. An evaluation of postabsorptive protein and amino acid metabolism in the lactating dairy cow. J. Dairy Sci. 81:3385-3401.

Hanigan, M. D., J. France, S. J. Mabjeesh, W. C. McNabb, and B. J. Bequette. 2009. High rates of mammary tissue protein turnover in lactating goats are energetically costly. J. Nutr. 139:1118-1127.

Hara, K., K. Yonezawa, Q. P. Weng, M. T. Kozlowski, C. Belham, and J. Avruch. 1998. Amino acid sufficiency and mTOR regulate p70 S6 kinase and eIF-4E BP1 through a common effector mechanism. J. Biol. Chem. 273:14484-14494.

Hay, N., and N. Sonenberg. 2004. Upstream and downstream of mTOR. Genes Dev. 18:1926-1945.

Hayashi, A. A., K. Nones, N. C. Roy, W. C. McNabb, D. S. Mackenzie, D. Pacheco, and S. McCoard. 2009. Initiation and elongation steps of mRNA translation are involved in the increase in milk protein yield caused by growth hormone administration during lactation. J. Dairy Sci. 92:1889-1899.

Houdebine, L.-M., J. Djiane, I. Dusanter-Fourt, P. Martel, P. A. Kelly, E. Devinoy, and J.-L. Servely. 1985. Hormonal action controlling mammary activity. J. Dairy Sci. 68:489-500.

Jenness, R. 1979. Comparative aspects of milk proteins. J. Dairy Res. 46:197-210.

Kimball, S. R., L. S. Jefferson, H. V. Nguyen, A. Suryawan, J. A. Bush, and T. A. Davis. 2000. Feeding stimulates protein synthesis in muscle and liver of neonatal pigs through an mTOR-dependent process. Am. J. Physiol. Endocrinol. Metab. 279:E1080-E1087.

Labarca, C., and K. Paigen. 1980. A simple, rapid, and sensitive DNA assay procedure. Anal. Biochem. 102:344-352.

Long, X., Y. Lin, S. Ortiz-Vega, K. Yonezawa, and J. Avruch. 2005. Rheb binds and regulates the mTOR kinase. Curr. Biol. 15:702713.

Ma, X. M., and J. Blenis. 2009. Molecular mechanisms of mTORmediated translational control. Nat. Rev. Mol. Cell Biol. 10:307318.

Mackle, T. R., D. A. Dwyer, K. L. Ingvartsen, P. Y. Chouinard, D. A. Ross, and D. E. Bauman. 2000. Effects of insulin and postruminal supply of protein on use of amino acids by the mammary gland for milk protein synthesis. J. Dairy Sci. 83:93-105.

Moshel, Y., R. E. Rhoads, and I. Barash. 2006. Role of amino acids in translational mechanisms governing milk protein synthesis in murine and ruminant mammary epithelial cells. J. Cell. Biochem. $8: 685-700$.

O'Connor, P. M., S. R. Kimball, A. Suryawan, J. A. Bush, H. V. Nguyen, L. S. Jefferson, and T. A. Davis. 2003. Regulation of translation initiation by insulin and amino acids in skeletal muscle of neonatal pigs. Am. J. Physiol. Endocrinol. Metab. 285:E40E53.

Park, C. S., and P. T. Chandler. 1976. Response to labeled precursor amino acids, varying cell density, and graded amino acid complement for protein synthesis in mammary cell culture. J. Dairy Sci. 59:216-223.

Proud, C. G. 2007. Signalling to translation: How signal transduction pathways control the protein synthetic machinery. Biochem. J. 403:217-234.

Purdie, N. G., D. R. Trout, D. P. Poppi, and J. P. Cant. 2008. Milk synthetic response of the bovine mammary gland to an increase in the local concentration of amino acids and acetate. J. Dairy Sci. $91: 218-228$.

Rhoads, R. E., and E. Grudzien-Nogalska. 2007. Translational regulation of milk protein synthesis at secretory activation. J. Mammary Gland Biol. Neoplasia 12:283-292.

Sancak, Y., and D. M. Sabatini. 2009. Rag proteins regulate aminoacid-induced mTORC1 signalling. Biochem. Soc. Trans. 37:289290

Sancak, Y., C. C. Thoreen, T. R. Peterson, R. A. Lindquist, S. A. Kang, E. Spooner, S. A. Carr, and D. M. Sabatini. 2007. PRAS40 is an insulin-regulated inhibitor of the mTORC1 protein kinase. Mol. Cell 25:903-915.

Sans, M. D., M. Tashiro, N. L. Vogel, S. R. Kimball, L. G. D'Alecy, and J. A. Williams. 2006. Leucine activates pancreatic translational machinery in rats and mice through mTOR independently of CCK and insulin. J. Nutr. 136:1792-1799.

SAS Institute. 2000. SAS/STAT User's Guide. Version 8. SAS Institute, Inc., Cary, NC.

Schingoethe, D. J., E. C. Hageman, and B. L. Larson. 1967. Essential amino acids for milk protein synthesis in the in vitro secretory cell and stimulation by elevated levels. Biochim. Biophys. Acta 148:469-474.

Shah, O. J., S. R. Kimball, and L. S. Jefferson. 2000. Glucocorticoids abate p70(S6k) and eIF4E function in L6 skeletal myoblasts. Am. J. Physiol. Endocrinol. Metab. 279:E74-E82.

Suryawan, A., P. M. O'Connor, S. R. Kimball, J. A. Bush, H. V. Nguyen, L. S. Jefferson, and T. A. Davis. 2004. Amino acids do not alter the insulin-induced activation of the insulin signaling pathway in neonatal pigs. J. Nutr. 134:24-30.

Toerien, C. A., and J. P. Cant. 2007. Abundance and phosphorylation state of translation initiation factors in mammary glands of lactating and nonlactating dairy cows. J. Dairy Sci. 90:27262734 .

Toerien, C. A., D. R. Trout, and J. P. Cant. 2004. Effect of nutrients on p70S6K activation in the bovine mammary gland. J. Anim. Feed Sci. 13(Suppl. 1):449-452.

Whitelaw, F. G., J. S. Milne, E. R. Orskov, and J. S. Smith. 1986. The nitrogen and energy metabolism of lactating cows given abomasal infusions of casein. Br. J. Nutr. 55:537-556.

Yang, X., C. Yang, A. Farberman, T. C. Rideout, C. F. de Lange, J. France, and M. Z. Fan. 2008. The mammalian target of rapamycinsignaling pathway in regulating metabolism and growth. J. Anim. Sci. 86(Suppl. 14):E35-E50. 